\title{
Bitkisel Tasarımda Kullanılabilecek Bilgi Sistemi ve Yazılımların Karşılaştırılması
}

\author{
Ömer Faruk UZUN ${ }^{1 *(D)}$, Atila GÜL ${ }^{2}$ \\ ORCID 1: 0000-0002-8541-4098 \\ ORCID 2: 0000-0001-9517-5388 \\ ${ }^{1}$ Sakarya Uygulamalı Bilimler Üniversitesi, Ziraat Fakültesi, Peyzaj Mimarlığı Bölümü, 54580, Sakarya, Türkiye \\ ${ }^{2}$ Süleyman Demirel Üniversitesi, Mimarlık Fakültesi, Peyzaj Mimarlığı Bölümü, 32260, Isparta, Türkiye. \\ *e-mail: omerfarukuzun@subu.edu.tr \\ Öz \\ Bu çalışmada; günümüzde mevcut bulunan ve bitkisel tasarıma yardımcı olabilecek nitelikteki online veri \\ tabanları, bilgi sistemleri, web siteleri ve bazı yazılımlar araştırılmış ve bu niteliklere sahip 5 adet program \\ seçilmiştir. Bunlar; Right Plants 4 Me web sitesi, Ağaçlar.Org Bitki Veri Tabanı, Shoot Gardening web uygulaması, \\ BITKIVT Online Bitki Veri Tabanı ve LikeThat Gardening akıllı telefon uygulaması gibi bilgisayar tabanlı \\ yazılımlardır. Seçilen yazılımların özellikleri incelenmiş olup belirlenen değerlendirme kriterleri baz alınarak uzman \\ anketi çalışması yapılmış ve anket sonuçlarına göre yazılımların bitkisel tasarıma yardımcı olması bakımından \\ avantaj ve dezavantajları ortaya konulmuştur. Buna göre; bitkisel tasarıma yardımcı olabilmesi bakımından, \\ BITKIVT Online Bitki Veri Tabanı ve Shoot Gardening web uygulaması diğer yazılımlara kıyasla daha avantajlı \\ olduğu belirlenmiştir.
}

Anahtar Kelimeler: Bitkisel tasarım, yazılım, bilgi sistemleri, veri tabanları, dijital peyzaj tasarımı

\section{The Comparison of Information Systems and Softwares Suitable for Planting Design}

\begin{abstract}
In this study; online databases, information systems, websites and some software that are available today that can help with planting design were researched and 5 programs with these qualities were selected. These are computer based software such as; Right Plants 4 Me website, Agaclar.org plant database, Shoot Gardening web app, BITKIVT Online plant database and LikeThat Gardening smartphone application. The features of the selected software have been examined and expert survey has been conducted based on the determined evaluation criteria, and according to the survey results, the advantages and disadvantages of the software in terms of helping with the planting design have been revealed. According to this; BITKIVT Online Plant Database and Shoot Gardening web application are determined to be more advantageous compared to other software in terms of helping with planting design.
\end{abstract}

Keywords: Planting design, software, information systems, databases, digital landscape design

Atıf/Citation: Uzun, Ö. F, Gül, A. (2021). Bitkisel Tasarımda Kullanılabilecek Bilgi Sistemi ve Yazılımların Karşılaştırılması. Journal of Architectural Sciences and Applications, 6 (1), 141-152. DOI: 10.30785/mbud.736138 


\section{Giriş}

Peyzaj Mimarlığı meslek disiplinini diğer tasarım tabanlı mesleklerden ayıran en önemli özelliklerden birisi canlı ve doğal olarak dinamik değişimler sergileyen bitkisel materyal ile tasarım yapmasıdır. Peyzaj tasarımı (yapısal ve bitkisel), belirlenen konsept ışı̆̆ında tasarım ögeleri, ilkeleri ve materyalleri kullanılarak tamamlanmaktadır. Bitkisel tasarım, bilimi, sanatı ve teknolojiyi birleştiren bir süreçtir. Bitkisel tasarım; bitkilerin ekolojik, estetik, fonksiyonel, sembolik ve psikolojik amaç, istek ve ihtiyaçlara göre tür seçimi, alan seçimi ve çevresi ile ilişkilendirilerek, özgün ve yaratıcılık gerektirecek biçimde, bütüncül, parçacıl ve obje bazında en ideal kompozisyon ya da çözümlerin üretildiği uygulamaya dönük işlemler bütünüdür (Gül, 2006).

Bitkisel tasarım kavramı; tasarım, bilim ve sanatın bir arada yürüdüğü bir süreçtir. Bu süreç, soyut anlamda bir konsept oluşturulmasını ve hem estetik hem de işlevsel, doğru ve amaca yönelik bir bitkisel tasarım planı üretmek için alanın çevresel ve ekolojik özellikleri ile bu soyutlamanın kombine edilmesini gerektirmektedir. Bir başka deyişle; bu süreç yetenek, görüş ve sabır gerektirmektedir (Leszczynski, 1999).

Bitkisel tasarım yapılırken alanın ekolojik özelliklerine, konsepte ve kullanıcı isteklerine uygun olacak şekilde öncelikle kullanılması düşünülen bitki listesi oluşturulur. Bitkilerin, tasarımı sınırlayacak birçok özelliği bulunmaktadır. Bitki listesi oluşturulurken, bu özelliklerin hepsi bir bütün olarak değerlendirilmeli, sorgulanmalı ve bu şekilde bir neticeye varılmalıdır. Bu sorgulamayı manuel olarak yapmak, birçok faktörü bir arada değerlendirip analiz etmeyi gerektirdiği için çok zor ve karmaşık olabilmektedir. Ancak bazı yazılım ve veri tabanları kullanarak bu sorgulamayı daha kolay ve hızlı bir şekilde yapmak mümkündür. Bunun sonucunda oluşturulan bitki listeleri çeşitli tasarım programları aracılığı ile bitkisel tasarım sürecinde kullanılabilmektedir.

Bitkisel tasarım konusunda bilgisayar ortamında oluşturulacak bir veri tabanı ile daha kapsamlı, etkili ve kolay şekilde sorgulamalar yapılması mümkündür (Eşbah ve Tunçay, 2005). Dijital peyzaj çalışmalarının, bitkisel tasarım uygulama proje sürecini hızlandırması, bitki tür seçimini ve amaca uygun çok kriterli karar verme süreçlerini kolaylaştırması, bitkileri üç boyutlu olarak görebilme gibi avantajları nedeniyle tercih sebebi kabul görmektedir (Olgun ve Yılmaz, 2014).

Bu çalışmada; günümüzde mevcut bulunan ve bitkisel tasarıma yardımcı olabilecek nitelikteki online veri tabanları, web siteleri ve bazı yazılımlar incelenmiş olup aralarında karşılaştırmalar yapılarak yazılımların bitkisel tasarıma yardımcı olması bakımından avantaj ve dezavantajları ortaya konulmuştur.

\section{Materyal ve Yöntem}

\subsection{Materyal}

Peyzaj Mimarlığı meslek disiplinini diğer tasarım temelli mesleklerden ayıran önemli özelliklerinden birisi canlı materyal olan bitkileri kullanarak bitkisel tasarım yapmasıdır. Bitkisel tasarım süreci bitkisel materyalin özellikleri, tasarım öge ve ilkeleri ve proje alanının ekolojik özellikleri gibi birçok faktörün bir arada değerlendirilip tamamlandığı karmaşık bir süreçtir. Günümüzde böyle karmaşık süreçleri daha hızlı ve kolay hale getirebilmek için teknolojiyi kullanabilmek büyük ölçüde önemli hale gelmiştir.

Çalışmanın materyalini yazılım, web sitesi ve online veri tabanı karakterinde olma özellikleri göz önünde bulundurularak seçilen ve bitkisel tasarım ile ilişkili olabilecek Right Plants $4 \mathrm{Me}$ web sitesi, Ağaçlar.org Bitki Veri Tabanı, Shoot Gardening web uygulaması, BITKIVT Online Bitki Veri Tabanı ve LikeThat Gardening akıllı telefon yazııımı (android) oluşturmaktadır.

2.1.1. Right Plants 4 me web sitesi: Right Plants $4 \mathrm{Me}$; bahçe peyzaj tasarımı için, değişen hava koşullarına ve mevsimlere göre, doğru bitki seçimi ve bitki bakımı konuları üzerine oluşturulmuş web sitesi olup aynı zamanda çevrimiçi bir ansiklopedidir (Şekil 1) (RightPlants4Me, 2016). 


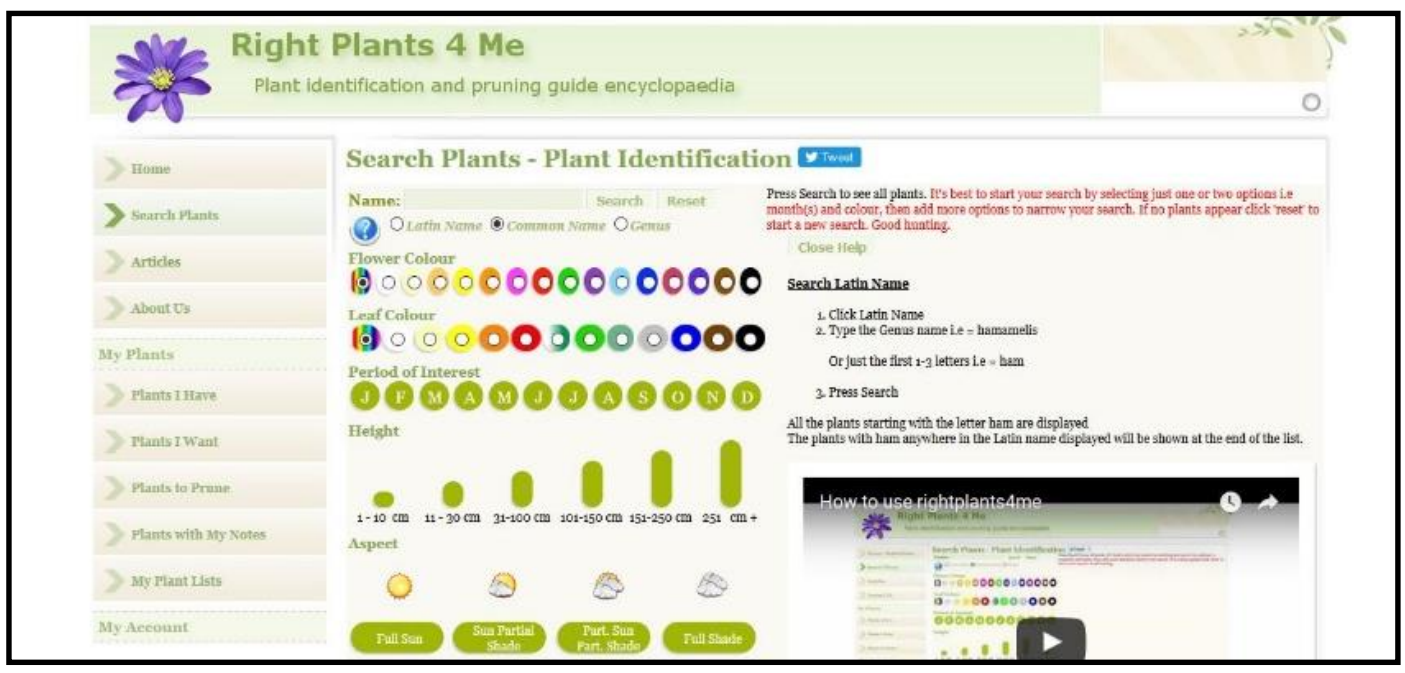

Şekil 1. Right Plants 4 Me Online Bitki Ansiklopedisi web sitesi (RightPlants4Me, 2016)

Bu web sitesini kullanarak bitkileri; botanik (latince) ismine göre, yerel ismine göre, tür ismine göre aramaları yapılabilmekte olup arama sonucunda bitkinin, fotoğrafı, sistematik adlandırması, alttür ve varyeteleri, ulaşabileceği boy, tepe taç genişliği, soğuğa dayanıklılık derecesi, ekolojik istekleri ve özellikleri, bitkinin zararlıları ve hastalıkları, bitkinin üretim, dikim ve bakım bilgileri gibi birçok ayrıntılı anlatımlara ulaşılabilmektedir (Şekil 2).

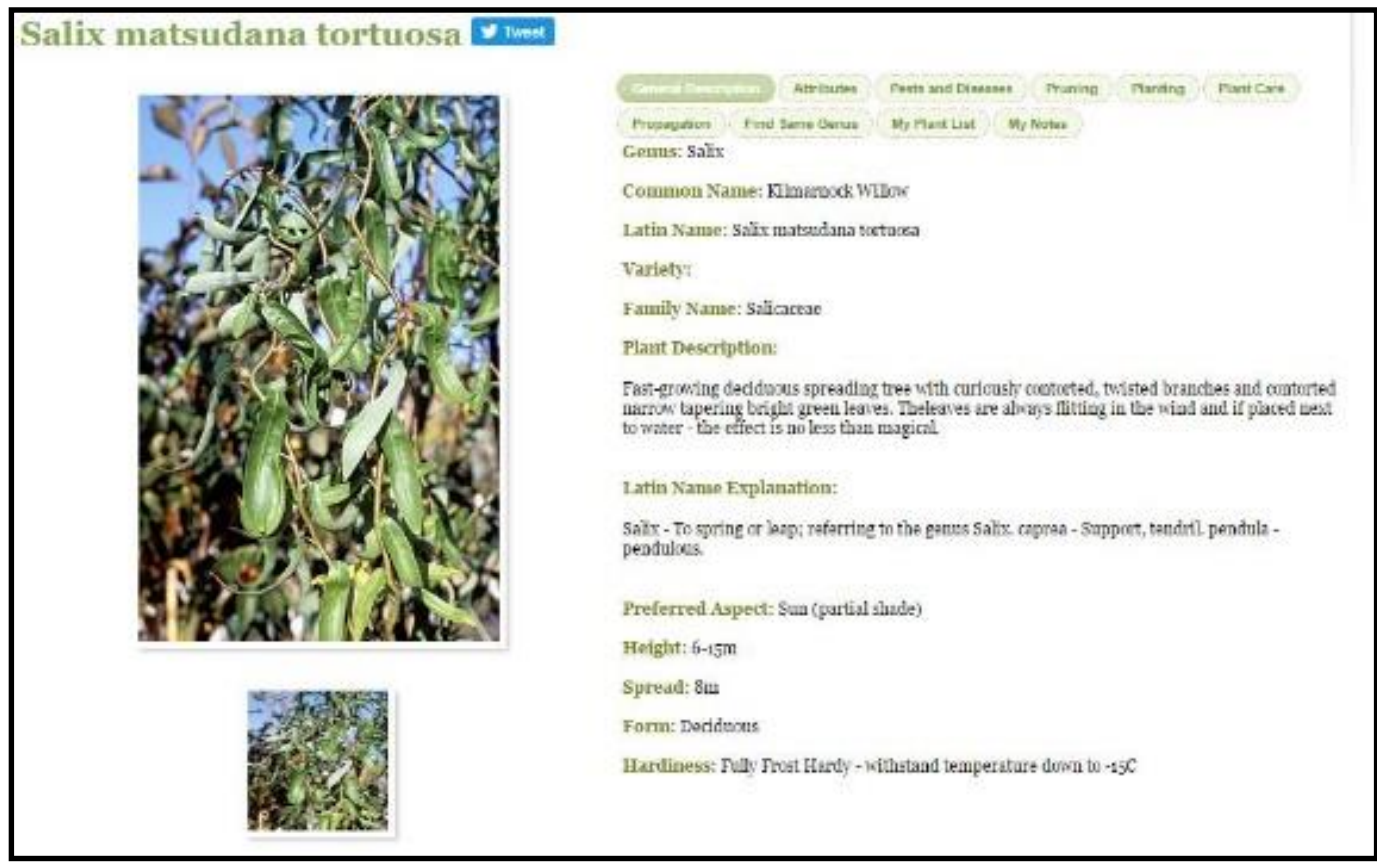

Şekil 2. Right Plants 4 Me isme göre bitki sorgulama sonucu (RightPlants4Me, 2016)

Right Plants 4 Me web sitesi ile bitkisel tasarım yapacağımız alanın özellikleri (toprak yapısı, iklim durumu vb.) ve kullanacağımı bitkinin karakterlerine göre (çiçek rengi, çiçeklenme periyodu, boyu, güneş sevmesi vb.) de sorgulama yapmakta olup girdiğimiz verilere uygun bitki türlerini ve bunların özelliklerini önümüze sunabilmektedir (Şekil 3). 


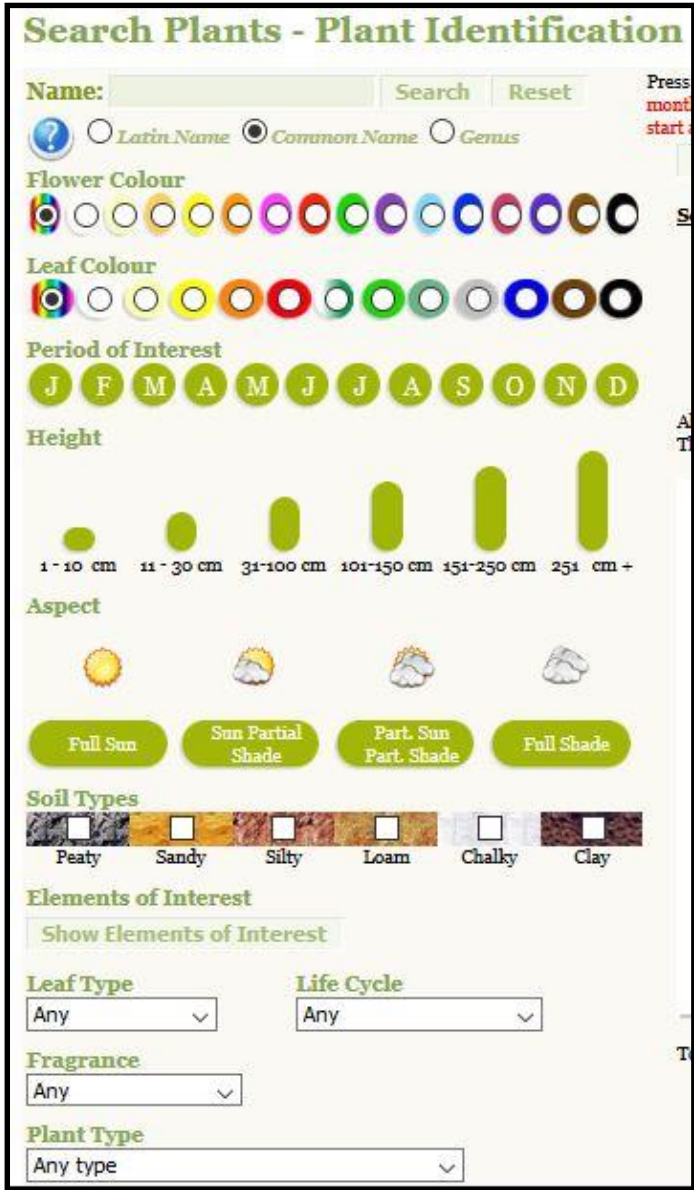

Şekil 3. Özelliklere göre bitki türü sorgulama ekranı (RightPlants4Me, 2016)

2.1.2. Ağaçlar.org bitki veri tabanı: Ağaçlar.org Bitki veri tabanı 2004 yılında, Türkiye'de yetişen bitkilerin fotoğraflarını ve birçok bilimsel özelliklerini barındırması amacıyla, online bir biçimde oluşturulan ve açık tabanlı olup üyelerinin veri tabanına katkı yapmasına imkan veren, bir bitki veri tabanı web sitesidir (Şekil 4) (Ağaçlar.org, 2016).

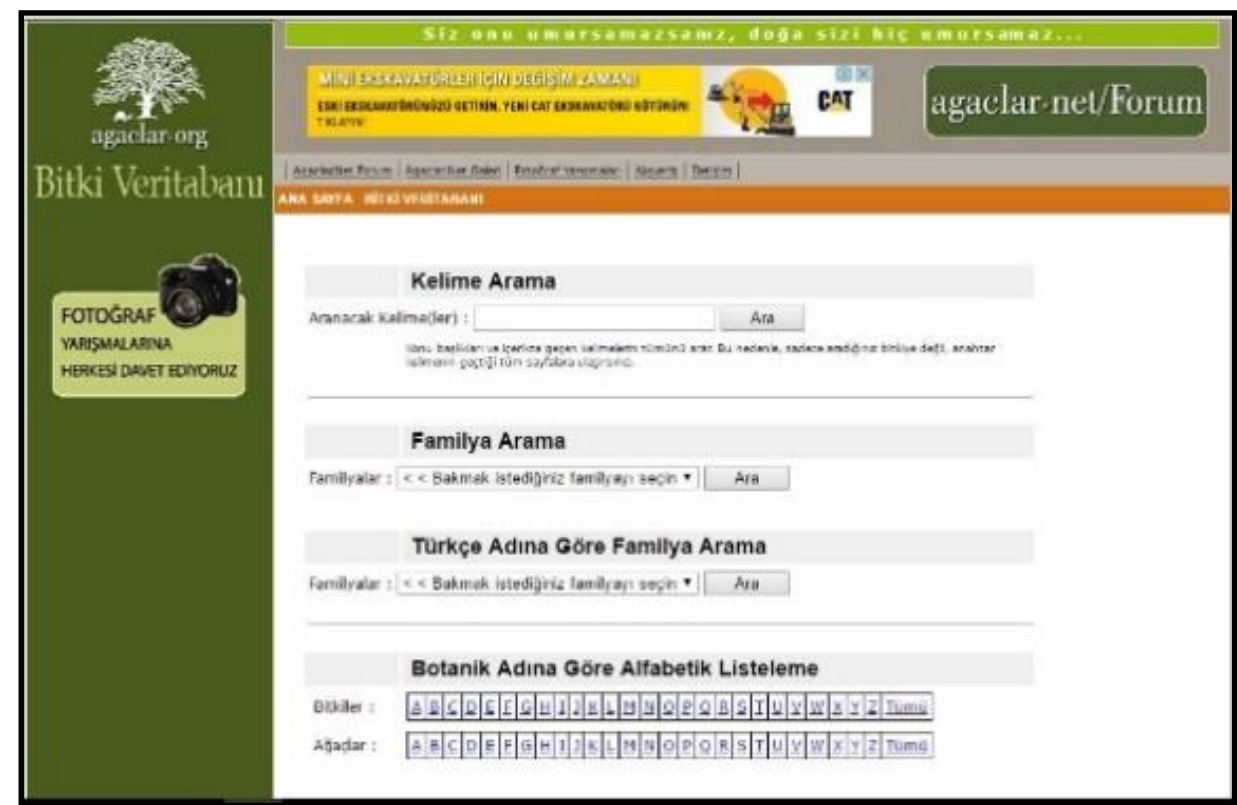

Şekil 4. Ağaçlar.org bitki veri tabanı web sitesi (Ağaçlar.org, 2016)

Bu veri tabanı sayesinde bitkileri; botanik (Latince), yerel ve familya ismine göre sorgulanabilmekte olup, sonucunda bitki kısımlarının fotoğrafları, sistematik adlandırması, doğal yetişme alanı, alttür ve varyeteleri, morfolojik özellikleri, ulaşabileceği boy, tepe taç genişliği, soğuğa dayanıklılı derecesi, 
ekolojik istekleri ve özellikleri, bitkinin zararlıları ve hastalıkları, bitkinin üretim, dikim ve bakım bilgileri, peyzajda uygun kullanım alanları ve kullanım dezavantajları gibi birçok ayrıntılı bilgiye ulaşılabilmektedir (Şekil 5).

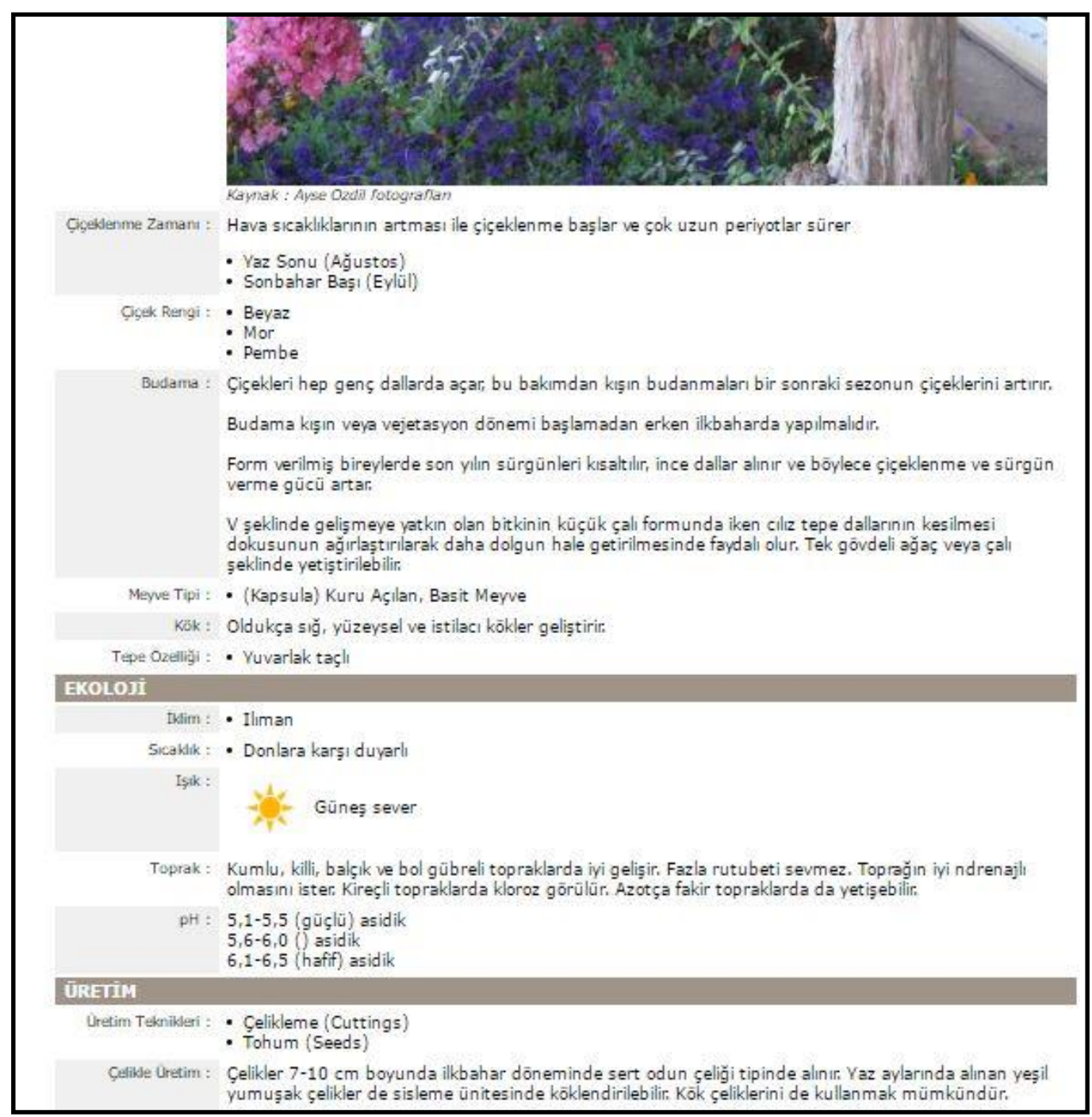

Şekil 5. Ağaçlar.org bitki veri tabanı isme göre sorgulama sonucu ekranı (Ağaçlar.org, 2016)

2.1.3. Shoot Gardening web uygulaması: Shoot Gardening, Nicola Gammon tarafından 2004 yılında oluşturulan ve sürekli geliştirilmekte olan, bahçe tasarımı yapmayı kolaylaştıran, bahçecilik ve peyzaj tasarımı hakkında gerekli bilgi ve materyali içinde barındıran bir web uygulamasıdır (ShootGardening, 2016). Shoot Gardening, web sitesi ve web uygulaması olmak üzere iki modülden oluşmaktadır.

Web Sitesi: Shoot Gardening'in web sitesi modülünde, bitki veri tabanı bulunmakta olup bu veri tabanından bitki ismine (botanik ismi), familyasına, tür adına göre ve aynı zamanda çeşitli bitki özelliklerine göre de sorgulamalar yapılabilmektedir. Sorgulamalar sonucunda; bitki kısımlarının fotoğrafları, sistematik adlandırması, doğal yetişme alanı, alttür ve varyeteleri, morfolojik özellikleri, ulaşabileceği boy, tepe taç genişliği, soğuğa dayanıklılık derecesi, ekolojik istekleri ve özellikleri, bitkinin zararlıları ve hastalıkları, bitkinin üretim, dikim ve bakım bilgileri, peyzajda uygun kullanım alanları gibi birçok ayrıntılı bilgiye ulaşılabilmektedir (Şekil 6). 


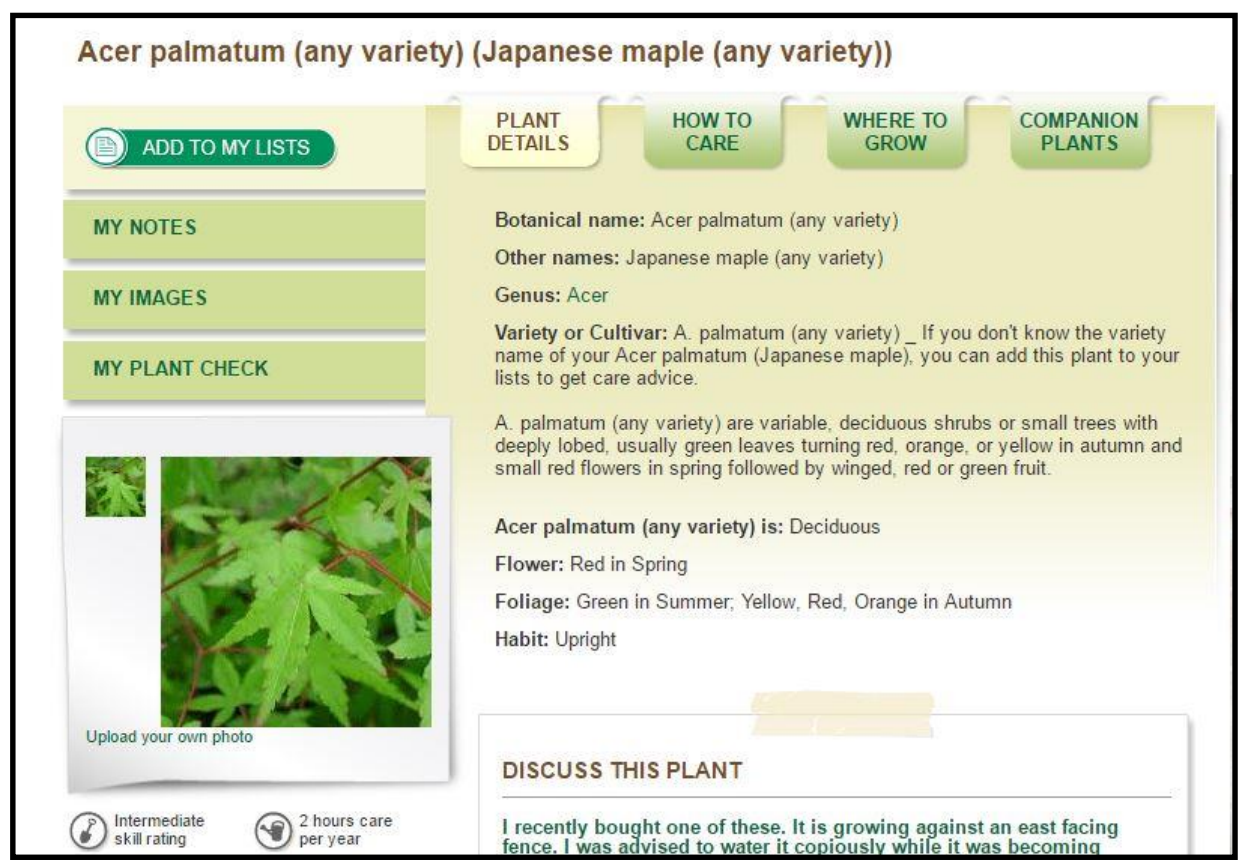

Şekil 6. Shooting garden bitki türü sorgulama ekranı (ShootGardening, 2016)

Web Uygulaması: Shooting Garden'ın web uygulaması modülünde, bitkisel tasarımda kullanmak istediğiniz türlerin eklenmesi ve tasarım yapacağımız alanın ekolojik özellik verilerini (iklim, toprak durumu, yükseklik, bakı vb.) girilmesi suretiyle yazılım sorgulama yapmaktadır. Sorgulama sonucunda kullanmak istediğimiz bitkilerin çalışma alanımıza ekolojik istekleri açısından uygun olup olmadığı ortaya çıkarmakta ve daha uygun olabilecek bitki türleri de yazılım tarafından önerilmektedir (Şekil 7).

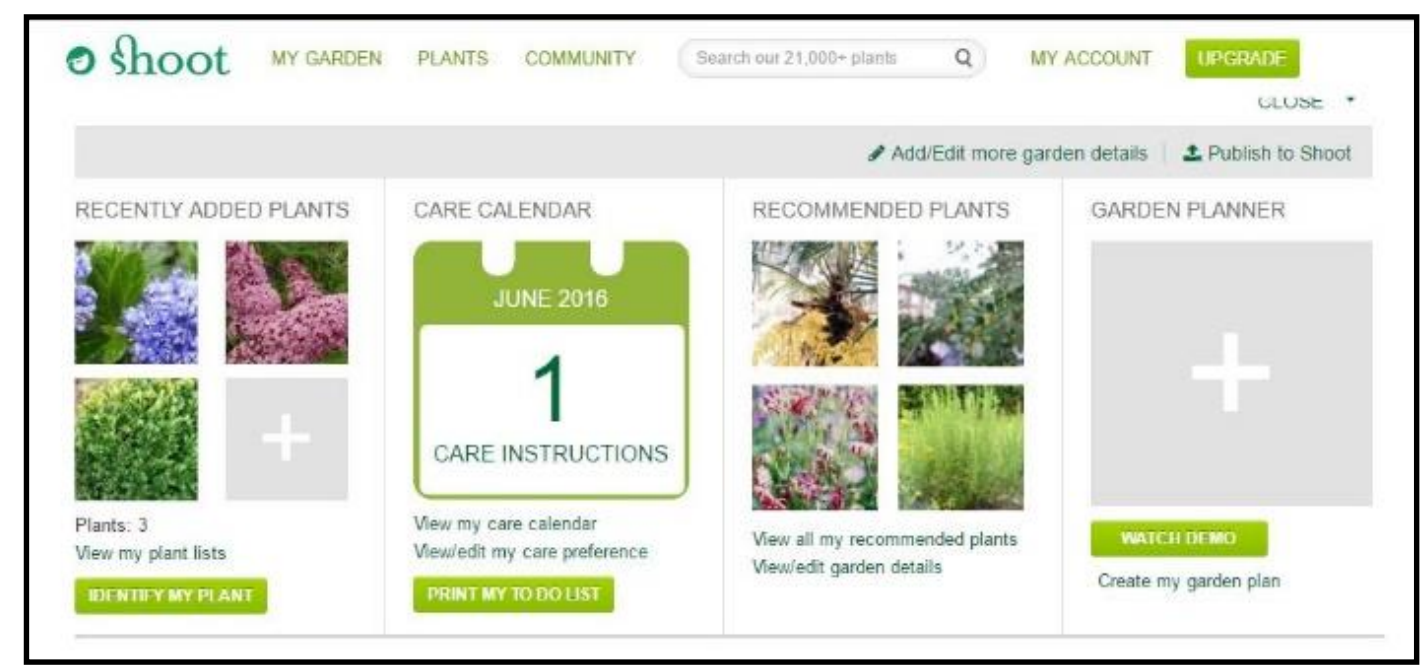

Şekil 7. Shooting garden web uygulaması modülü sorgulama sonucu ekranı (ShootGardening, 2016)

Ayrıca bir çizim ekranı bulunduran bu web uygulaması modülünde, çalışma alanının ölçüleri boyutunda alan çizilerek ve otomatik olarak tepe taç genişliği gibi ölçüler ile seçilen bitkiler kullanılarak bitkisel tasarım için kolayca ön eskiz çalışması yapılabilmektedir (Şekil 8). 


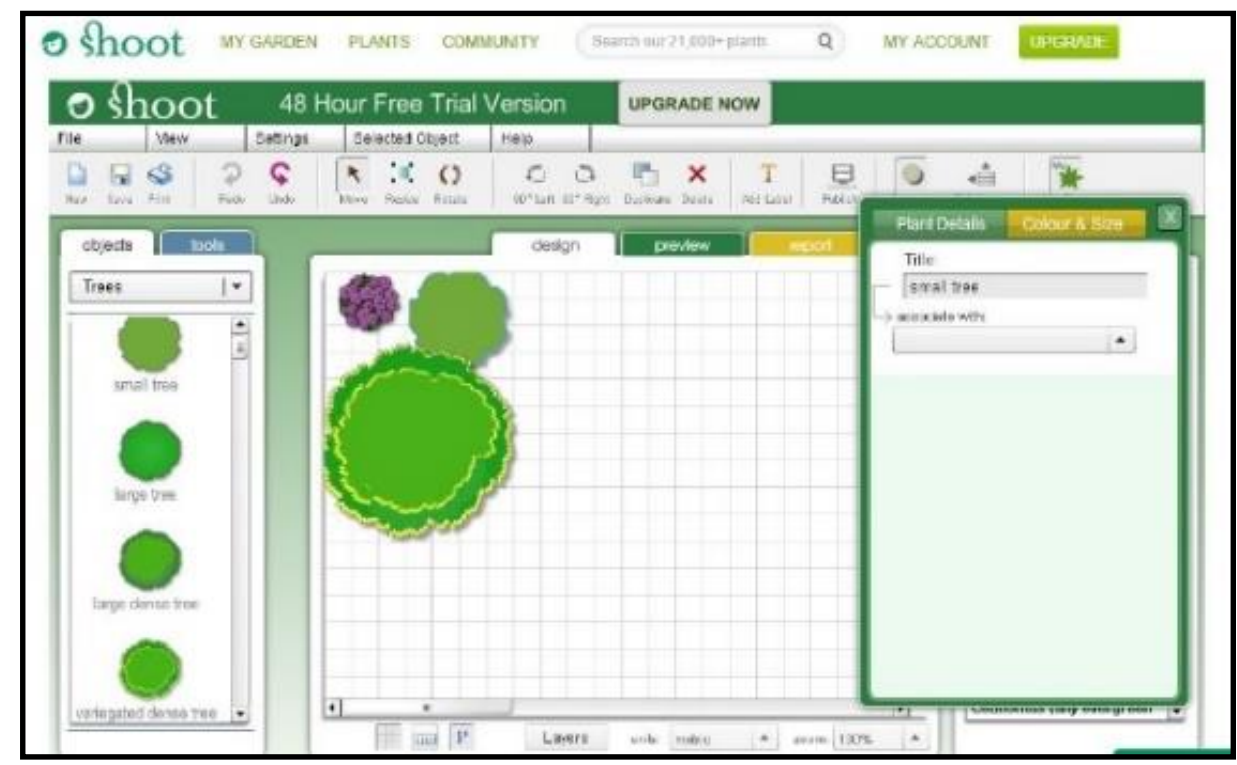

Şekil 8. Shooting garden web uygulaması çizim ekranı (ShootGardening, 2016)

2.1.4. BITKIVT dijital veri tabanı: Bu bitki veri tabanı sayesinde bitkiler; botanik (latince) ismine göre, yerel ismine göre sorgulanabilmekte olup, sonucunda bitki kısımlarının fotoğrafları, sistematik adlandırması, doğal yetişme alanı, botanik özellikleri, ulaşabileceği boy, tepe taç genişliği, soğuğa dayanıklılık derecesi, ekolojik istekleri ve özellikleri, bitkinin zararlıları ve hastalıkları, bitkinin üretim, dikim ve bakım bilgileri, peyzajda uygun kullanım alanları ve kullanım dezavantajları, kullanım amaçları gibi birçok ayrıntılı bilgiye Şekil 9'da gösterildiği gibi ulaşılabilmektedir (BITKIVT, 2016).
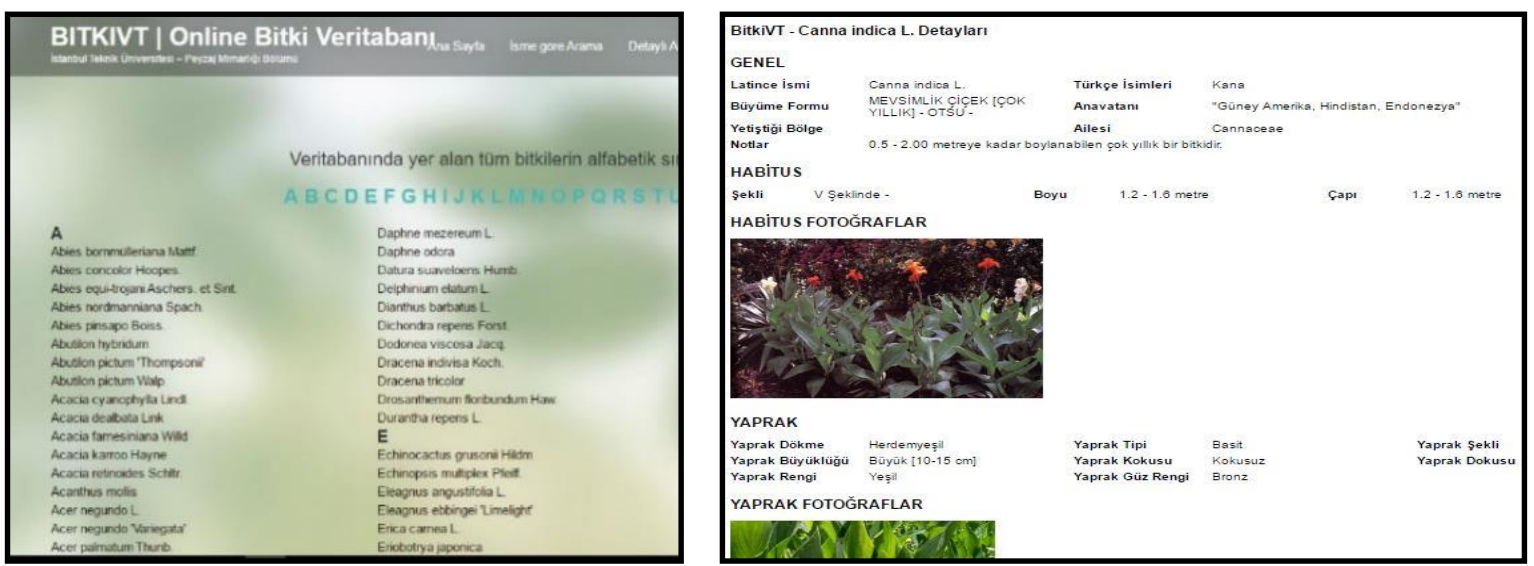

Şekil 9. BITKIVT online bitki veri tabanı isme göre sorgulama ekranı (BITKIVT, 2016)

Ayrıca detaylı arama kısmından bitkileri, tepe taç genişliği, boyu, morfolojik özelliği, botanik özellikleri, ekolojik istekleri, çiçeklenme zamanı, kullanım amacı, kullanım alanı, yetiştiği bölgeler vb. gibi birçok özelliğine göre sorgulama yapmakta olup seçici yapılan özelliklere uygun bitki türlerini ve bunların özelliklerini kullanıcılara sunabilmektedir (Şekil 10). 


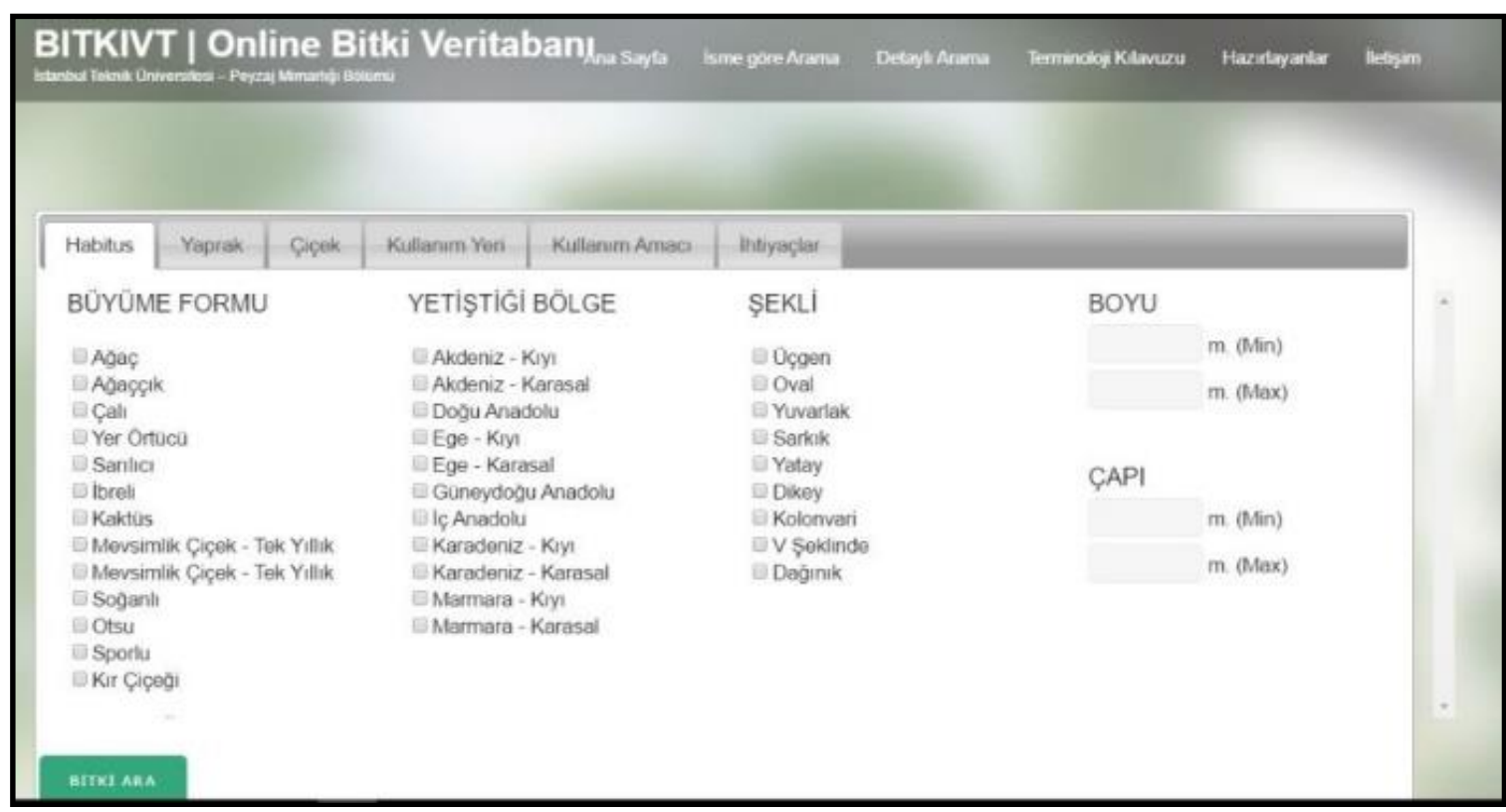

Şekil 10. BITKIVT Online Veri Tabanı detaylı arama ekranı (BITKIVT, 2016)

2.1.5. LikeThat Garden mobil uygulaması: Android tabanlı akıllı telefon uygulaması olan LikeThat Garden yazılımı, bitkileri akıllı telefon kamerası ile fotoğrafladıktan sonra, görüntü işleme motoru ile analiz ederek, bitkileri kolayca teşhis etmeye, teşhisi doğrulanan bitki türünün bilimsel sınıflandırma ve özellikleri gibi bilgileri de Vikipedia internet ansiklopedisi aracılı̆̆ı ile kullanıcılara sunabilmektedir (Şekil 11) (LikeThatGarden, 2019).

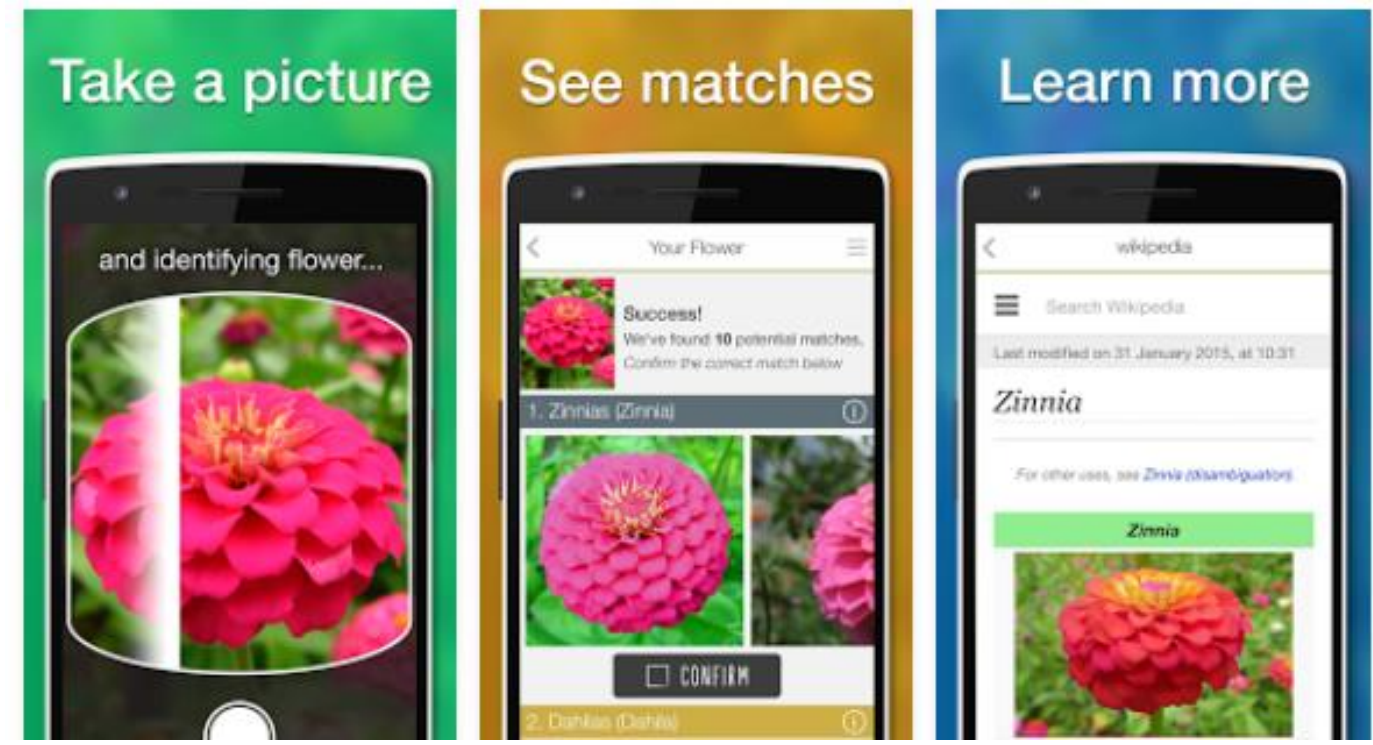

Şekil 11. Fotoğraf çekme işlemi ile bitki teşhisi yapılması (LikeThatGarden, 2019)

Bu uygulamanın akıllı telefona entegre edilmiş olması kullanıcıya özellikle bitki teşhisi konusunda pratik çözüm ortaya koyabilmektedir.

\subsection{Yöntem}

Bu çalışmada, konu ile ilgili olabileceği düşünülen yerli ve yabancı tüm veriler hakkında, literatür ve internet taraması yapılmıştır. Tarama sonucunda bitkisel tasarıma yardımcı olabilecek ve bu amaçta kullanılabilecek bazı veri tabanı, yazılım ve web sitelerine ulaşılmıştır. Söz konusu programlardan, bitki bilgi sistemi, yazılım, web sitesi ve online veri tabanı karakterinde olma hususları göz önünde bulundurularak çalışma materyali olmak üzere 5 tanesi seçilmiştir. Ardından ilgili materyallerin bitkisel tasarıma yardımcı olma kapasiteleri açısından özellikleri araştırılmıştır. Bu kapsamda, söz konusu yazılımların, bitkisel tasarımda kullanımına yönelik avantaj ve dezavantajlarının belirlenebilmesi için beş adet değerlendirme ölçütü ortaya konulmuştur (Çizelge 1). 
Çizelge 1. Yazılımların kıyaslanabilmesi için oluşturulan değerlendirme ölçütleri

\begin{tabular}{cl}
\hline No & Değerlendirme Ölçütleri \\
\hline 1 & Bitki teşhis özelliği \\
2 & $\begin{array}{l}\text { Eskiz, çižim vb. özelliği ile tasarıma yardımcı olabilme } \\
\text { özelliği }\end{array}$ \\
3 & Bitki veri tabanı zenginliği \\
4 & Bitki verilerini detaylı sorgulama olanağı \\
5 & Bitki tür öznitelik bilgileri yeterliliği \\
\hline
\end{tabular}

Belirlenen değerlendirme ölçütleri ile oluşturulan anket çalışması, lisansüstü düzeyindeki (yüksek lisans ya da doktora yapan veya mezun olanlar) Peyzaj Mimarlarından oluşan 20 kişilik uzman gruba uygulanmıştır. Bu bağlamda, ankete katılanlar bitkisel tasarım kavramına ve süreçlerine yönelik yeterli bilgi, beceri ve yetkinliklere sahip oldukları düşünülerek tercih edilmiştir. Çalışmada öncelikle ilgili uzmanlara söz konusu 5 farklı yazılıma ilişkin bilgilendirme yapılmış ve ardından 3'lü likert ölçeği (1 puan uygun değil, 3 puan orta uygunlukta ve 5 puan ise çok uygun) kullanılarak ilgili ölçütler puanlandırılmıştır.

Likert ölçeğinin temel hedefi, bireylerin belirli tutumlar karşısındaki tepkilerini derecelendirmektir. Ayrıca bireylerin yalnızca bir tutum cümlesine karşı olup olmadıkları değil, tutumlarının derecesini de ölçmek istemesidir (Barlas ve ark., 1985). Uzmanlar tarafından Likert ölçeğine göre yapılan puanlama sonucunda; programların aldıkları toplam puanlar, Çizelge 2'de verilen kıyaslama ölçeği temel alınarak değerlendirilmiştir.

Çizelge 2. Kıyaslama ölçeği

\begin{tabular}{c|c}
\hline Puan Aralığı & Değerlendirme Ölçeği \\
\hline $0-33$ & Avantajlı değil \\
\hline $34-66$ & Orta derecede avantajlı \\
\hline $67-100$ & Yüksek derecede avantajlı
\end{tabular}

Buna göre; her bir ölçüte göre hangi yazııımın ne kadar avantajlı olduğu ortaya konulmuş olup toplam puan bazında öne çıkan yazılımlar ise bitkisel tasarımda yardımcı olabilecek araçlar olarak önerilmiştir.

\section{Bulgular}

\section{1. Çalışmada Kullanılan Yazılımların Karşılaştııılması}

Çalışmada bitki bilgi sistemi, yazılım, web sitesi ve online veri tabanı karakterine sahip olan 5 adet yazılım Çizelge 1'deki ölçütler çerçevesinde avantaj ve dezavantajlarını belirlemek amacıyla Uzman Peyzaj Mimarlarına uygulanan anket ile puanlanmıştır. Ankete katılan uzmanların genel profili ise Çizelge 3'te verilmiştir.

Çizelge 3. Ankete katılanların genel profili

\begin{tabular}{llc} 
Uzmanların genel profili & Yüzde (\%) değerleri \\
\hline Cinsiyet & Kadın & 60 \\
& Erkek & 40 \\
\hline Yaş Grupları & $21-26$ yaş grubu & 80 \\
& $27-35$ yaş grubu & 20 \\
\hline Eğitim Düzeyi & Yüksek Lisans devam eden / mezun olanlar & 70 \\
& Doktoraya devam eden / mezun olanlar & 30 \\
\hline
\end{tabular}

Çalışmanın materyalindeki programların değerlendirme ölçütlerine göre uzman anketi sonucunda aldığı puanlar Çizelge 4 'te ortaya konulmuştur. 
Çizelge 4. Uzman anketi sonuçları

\begin{tabular}{|c|c|c|c|c|c|c|}
\hline No & Değerlendirme Ölçütleri & 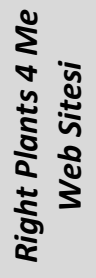 & 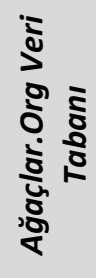 & 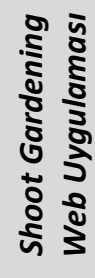 & 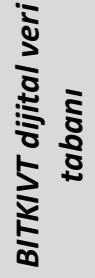 & 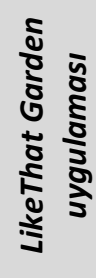 \\
\hline 1 & Bitki teşhis edebilme özelliği & 20 & 20 & 20 & 20 & 94 \\
\hline 2 & $\begin{array}{l}\text { Eskiz, çizim vb. özelliği ile tasarıma yardımcı } \\
\text { olabilme özelliği }\end{array}$ & 24 & 20 & 84 & 20 & 20 \\
\hline 3 & Bitki veri tabanı zenginliği & 36 & 82 & 28 & 38 & 78 \\
\hline 4 & Bitki verilerini detaylı sorgulama olanağı & 70 & 28 & 56 & 86 & 28 \\
\hline \multirow[t]{2}{*}{5} & Bitki tür öznitelik bilgileri yeterliliği & 30 & 80 & 64 & 90 & 26 \\
\hline & Toplam Puan & 180 & 230 & 252 & 254 & 226 \\
\hline
\end{tabular}

Çalışma yöntemi çerçevesinde, uzman anketi sonucunda söz konusu yazılımların aldıkları puanlar Çizelge 4'te verilmiştir. Bu puanlar, Çizelge 2'deki kıyaslama ölçeği kullanılarak değerlendirilmiş ve değerlendirme ölçütlerine göre yazılımların avantaj ve dezavantajlarının düzeyleri belirlenmiştir. Bu bağlamda;

- Right Plants 4 Me web sitesinin değerlendirme ölçütlerine göre aldığı puanlar incelendiğinde, bitki teşhis edebilme özelliği, eskiz, çizim vb. özelliği ile tasarıma yardımcı olabilme özelliği ve bitki tür öznitelik bilgileri yeterliliği ölçütleri bakımından avantajlı olmadığı, bitki veri tabanı zenginliği açısından orta derecede avantajlı olduğu ve bitki verilerini detaylı sorgulama olanağı yönünden de yüksek derecede avantajı olduğu görülmektedir.

- Ağaçlar.org veri tabanının değerlendirme ölçütlerine göre aldığı puanlar incelendiğinde, bitki teşhis edebilme özelliği, eskiz, çizim vb. özelliği ile tasarıma yardımcı olabilme özelliği ve bitki verilerini detaylı sorgulama olanağı ölçütleri bakımından avantajlı olmadığı fakat bitki veri tabanı zenginliği ve bitki tür öznitelik bilgileri yeterliliği açısından yüksek derecede avantajı olduğu ortaya çıkmıştır.

- Shoot Gardening web uygulamasının değerlendirme ölçütlerine göre aldığı puanlar incelendiğinde, bitki teşhis edebilme özelliği ve bitki veri tabanı zenginliği ölçütleri açısından avantajı olmadığı, bitki verilerini detayıı sorgulama olanağı ve bitki tür öznitelik bilgileri yeterliliği bakımından orta derecede avantajı olduğu, eskiz, çizim vb. özelliği ile tasarıma yardımcı olabilme özelliği yönünden ise yüksek derecede avantajı olduğu anlaşılmaktadır.

- BITKIVT dijital veri tabanının değerlendirme ölçütlerine göre aldığı puanlar incelendiğinde, bitki teşhis edebilme ve eskiz, çizim vb. özelliği ile tasarıma yardımcı olabilme özelliği ölçütleri açısından avantajlı olmadığı, bitki veri tabanı zenginliği yönünden orta derecede avantajı olduğu, bitki verilerini detaylı sorgulama olanağı ve bitki tür öznitelik bilgileri yeterliliği bakımından ise yüksek derecede avantajlı olduğu görülmektedir.

- LikeThat Garden uygulamasının değerlendirme ölçütlerine göre aldığı puanlar incelendiğinde, eskiz, çizim vb. özelliği ile tasarıma yardımcı olabilme özelliği, bitki tür öznitelik bilgileri yeterliliği ve bitki verilerini detaylı sorgulama olanağı ölçütleri açısından avantajlı olmadığı fakat bitki veri tabanı zenginliği ve bitki teşhis edebilme özelliği bakımından ise yüksek derecede avantajlı olduğu ortaya çıkmıştır.

Söz konusu yazılımlar aldıkları toplam puanlar üzerinden değerlendirildiğinde; BITKIVT dijital veri tabanı ve Shoot web uygulaması yazılımları diğerlerine göre daha avantajlı olarak öne çıkmakta olup bitkisel tasarım çalışmalarına yardımcı olabilecek araçlar olabilmesi açısından önerilmektedir.

\section{Sonuç ve Öneriler}

Günümüzde, her geçen gün hızla ilerleyen teknolojik gelişmeler (donanımlar, akıllı telefon uygulamaları, web uygulamaları, çeşitli yazılımlar) peyzaj mimarlığı meslek disiplini içinde başarı ve 
kalitenin olmazsa olmazı haline gelmiştir. Teknolojinin planlama ve tasarım süreçlerinde, projelendirme aşamasında hız kazandırması, geleneksel metotlarla yapılması zor olan aşamaları kolaylaştırması, maliyetinin düşük olması, kesin sonuçlar vermesi ve yapılan tasarımların görselliğini gerçeğine yakın ve 3 boyutlu olarak görebilme imkânı sunması gibi avantajlar, dijital peyzaj tasarımının meslek disiplini içerisinde, büyük öneme sahip olduğunu ortaya koymaktadır. Bu kapsamda; çalışmada bitkisel tasarım süreçlerinde yaşanan sıkıntı ve zorlukların çözümüne yönelik yeni yaklaşımlar ortaya konulmuştur. Bitkisel tasarım sürecinde; kullanılacak bitki türü seçiminde, bitkilerin özellikleri, tasarım ögeleri, ilkeleri, uygulanacak alanın özellikleri gibi faktörlerin hepsi bir bütün olarak sorgulanmalı ve bir neticeye varılmalıdır. Bu sorgulamayı manuel olarak yapmak, birçok faktörü bir arada değerlendirip analiz etmeyi gerektirdiği için çok zor ve karmaşık olabilmektedir. Fakat bazı yazılım ve veri tabanları kullanarak bu sorgulamayı yapmak mümkündür. Bu yazılımlar ile yapılacak olan sorgulama, ekolojik istekler, botanik özellikler ve çalışma alanının yapısına yönelik özellikler gibi bitkisel tasarımı direkt etkileyen özellik ve kriterlerin hepsini bütünü ile ele alıp sorgulayabileceğinden dolayı daha doğru sonuçlar verebilecektir. Böylece; tasarımda kullanılacak bitki türü seçimi ve akabinde yapılacak bitkisel tasarım çalışmaları daha ekolojik, amaca daha uygun ve sürdürülebilirliğe daha yakın uygulamalar söz konusu olacaktır.

Bu çalışmada; günümüzde mevcut bulunan ve bitkisel tasarıma yardımcı olabilecek nitelikteki online veri tabanları, web siteleri ve bazı yazılımlar incelenmiş olup aralarında karşılaştırmalar yapılarak yazılımların bitkisel tasarıma yardımcı olması bakımından avantaj ve dezavantajları ortaya konulmuştur. Buna göre; seçilen 5 adet programın her biri bitkisel tasarımdaki farklı bir iş aşamasında yardımcı olabilecek araçlar olduğu ortaya çıkmıştır. Ancak, bitkisel tasarım bir bütün olarak ele alınan bir süreçtir. Bu sebeple bu yazılımların yeniden ele alınıp veri tabanı zenginleştirmesi gerekmektedir.

Seçilen programlardaki bulunan farklı farklı özelliklerin bitkisel tasarıma yönelik yapılacak olan yazılımda; bitki fotoğrafından, bitki tanıma ve teşhis özelliğinin geliştirilmesi, bitki tür seçimi sorgulama sistemlerinin revize edilip zenginleştirilerek güncellenmesi, eskiz, çizim ekranı gibi bitkisel tasarıma yardımcı olabilecek modüllerin geliştirilmesi ve eklenmesi, bitki türlerine yönelik, tasarım programlarında kullanabileceğimiz 2 ve 3 boyutlu ortamlarda hazırlanmış plan, kesit görünüş ve 3 boyutlu model dosyalarının eklenmesi ve tasarım öge ve ilkeleri ile sorgulamaların yapılabilmesi gibi birçok karmaşık özelliği bir arada bulunduran ve algoritmasıyla bunların sorgulamalarını yapabilen çok kapsamlı ve Peyzaj Mimarlı̆̆ meslek disiplinine paralel kurgulanmış yazılımlara, modellere ve bilgi sistemlerine intiyaç duyulmaktadır. Böylelikle daha ekolojik, sürdürülebilir ve amaca uygun tasarımların yapılması doğanın bozulmadan korunmasına ve memnuniyet verici peyzaj uygulamalarının ortaya çıkartılmasına olumlu katkılar sağlanabilecektir.

\section{Teşekkür ve Bilgi Notu}

Makalede, ulusal ve uluslararası araştırma ve yayın etiğine uyulmuştur. Çalışmada etik kurul izni gerekmemiştir.

\section{Kaynaklar}

Ağaçlar.org, (2016). Ağaçlar.org bitki veri tabanı web sitesi. Erişim Adresi (05.05.2019): http://www.agaclar.org

Barlas, T., İsen, G. ve Batmaz, V. (1985). Ben ve toplum: sosyal psikoloji I. Teori Yayınları, 329s, Ankara.

BITKIVT, (2016). Online bitki veri tabanı web sitesi. Erişim Adresi (01.04.2021): http://www.bitkivt.itu.edu.tr

Eşbah, H. ve Tunçay, A. A. (2005). Peyzaj bitkilerine ilişkin özgün bir veritabanı geliştirilmesi. Adnan Menderes Üniversitesi Ziraat Fakültesi Dergisi, 2(2), 43-50. Online ISSN: 2717-7084, Erişim Adresi (10.04.2020): https://dergipark.org.tr/tr/pub/aduziraat/issue/26437/278315

Gül, A. (2006). Peyzaj amaçlı bitkisel materyaller, Ders Notu, SDÜ Orman Fakültesi, Peyzaj Mimarlı̆̆ı ve Orman Endüstri Bölümlerinin Ortak Projesi, Hafif İskeletli Ahşap Konut Yapımı ve Dış Mekân (Peyzaj) Düzenleme Eğitimi. Türkiye İş Kurumu (işKUR) ve Avrupa Birliği'nin Aktif İ̧̧ücü ve Yeni Firsatlar Programları Projesi, 76s, Isparta. 
Leszczynski, N. A., (1999). Planting the Landscape-A Professional Approach to Garden Design. John Wiley\&Sons Inc Publish, 208p, New York, USA.

LikeThatGarden, (2019). Like That Garden telefon uygulaması yazılımı tanıtımı. Erişim Adresi (01.11.2019): https://www.farms.com/agriculture-apps/gardening/like-that-garden-floweridentification

Olgun, R. ve Yılmaz, T. (2014). Peyzaj Mimarlığında Bilgisayar Destekli Tasarım ve Tasarım Aşamaları, Niğde Üniversitesi Mühendislik Bilimleri Dergisi, 3(1), 48-59. Online ISSN: 2564-6605, Erişim Adresi (03.03.2020): https://dergipark.org.tr/tr/pub/ngumuh/issue/22341/239370

RightPlants4Me. (2016). Right plants 4 me yazılımı web sitesi. Erişim Adresi (05.06.2016): https://www.rightplants4me.co.uk

Shoot Gardening, (2016). Shoot gardening yazılımı web sitesi. Erişim Adresi (02.05.2016): www.shootgardening. co.uk/page/what-is-shoot 